\title{
FISHING GROUNDS DYNAMICS OF PURSE SEINE FISHERIES IN THE JAVA SEA
}

\author{
Umi Chodriyah"1) and Eko Sri Wiyono') \\ 1) Researcher at Research Institute for Marine Fisheries, Muara Baru-Jakarta \\ 2) Lecturer in Faculty of Fisheries and Marine Science, Bogor Agricultural University, Bogor \\ Received February 1-2010; Received in revised form November 19-2010; Accepted December 21-2010
}

\begin{abstract}
Although information about fishing ground dynamics is very important to learn about the development of fishery, research on the dynamics of fishing ground is still rarely conducted. This study explains the fishing ground dynamics of purse seine in the Java Sea. The objective of this research was to study the fishing ground development of purse seine based in Pekalongan Nusantara Fishing Port. A series of data for the periods of 2002-2007 were collected by Research Institute for Marine Fisheries concerning the information on the months for fishing, boat names, boat size (gross tonnesnage), fishing ground, and catch composition. The results showed that the operation of seiners was not determined by a fish catching season since seiners could be found in any season in the fishing ground. During the west monsoon season and intermonsoon season I, the concentration of the seiners Pekalongan was in the waters of Lumu-Lumu, Lari-Larian, and Kota Baru (Makassar Straits). During the east monsoon season the seiners were concentrated in the waters of Pejantan Island, Natuna, Midai, Tarempa, Tambelan (South China Sea), and during the intermonsoon season II, they were concentrated in the waters around Masalima Island.
\end{abstract}

KEYWORDS: $\quad$ dynamics, fishing ground, purse seine, Java Sea

\section{INTRODUCTION}

The expansion and reduction in fishing fleets operation in relation with industrial fisheries will continue in connection with changes in fish resources abundance and other external factors. To overcome such limitations, the fishers will develop and apply particular fishing strategy to allocate the use of their fishing gears (Wiyono, 2007). Factors affecting fisheries dynamics comprise of internal and external factors. Internal factors related with fishing operations are capacity of fishing gear, boat capacity, and operational costs; while external factors are season and environmental conditions. One example of fisheries dynamics can be observed at purse seine fishery based in Pekalongan Nusantara Fishing Port, which functions as station base of fishing fleets and fishermen who conduct their fishing operation in several regional waters, particularly Java Sea.

Comprehensive understanding towards fish resources and human resources, included therein dynamics, and complex interactions, can provide excellent information for the purpose of formulating management policy in overcoming existing problems. During initial phase of sustainable fisheries management effort, research on fishing ground dynamics of purse seine fleets in Java Sea is significant. The objective of this study is to analyze the development of fishing ground occupied by purse seine fleets based in Pekalongan Nusantara Fishing Port.

\section{MATERIALS AND METHODS}

Field surveys were carried out in two months, from August to September 2008 in Pekalongan Nusantara Fishing Port, Central Java. Data collected include primary and secondary data. Primary data obtained directly from field observations, interviews and discussions, as well as on recording available data and information in the related institutions. Secondary data were obtained from Pekalongan Nusantara Fishing Port, revealing information regarding fishing seasons, fishing boat (name and size in gross tonnesnage), fishing ground, as well as species composition.

Data collected were assembled, tabulated, processed, and analyzed using sequence of different methods to produce maps, tables, figures, and charts. In order to calculate the value of catch per unit of effort, a formula developed by Sparre \& Venema (1999) was used:

$$
\text { CPUE }=\frac{\text { Catch }}{\text { Effort }}
$$


where:

CPUE $=$ catch per unit of effort

Catch $=$ number of yield $(\mathrm{g}, \mathrm{kg}$, or tonnes)

Effort $=$ number of fishing effort (day, trip, and unit)

Information with regards to fishing ground will be classified and descriptively analyze to be featured in the form of map.

\section{RESULTS AND DISCUSSION}

\section{Purse Seine Yields}

From the results obtained, harvest of purse seine fisheries fluctuates during each month of observation. Average monthly harvest reached the highest (peak) of 3,799 tonnes occurred in October, and the lowest yield of 1,296 tonnes was in March (Figure 1).

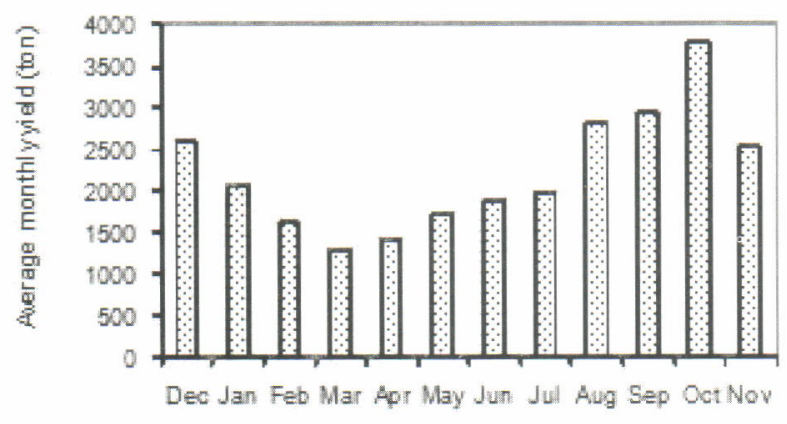

Figure 1.

The average monthly yield of purse seine fleet based in Pekalongan Nusantara Fishing Port, 2002-2007.

Similar profile of fluctuation also observed when comparing yield from different cumulative years, during the period of 2002-2007. The highest purse seine fisheries annual harvest of 54,127 tonnes was recorded in 2004, while the lowest yield of 3,219 tonnes was observed in 2002 (Figure 2).

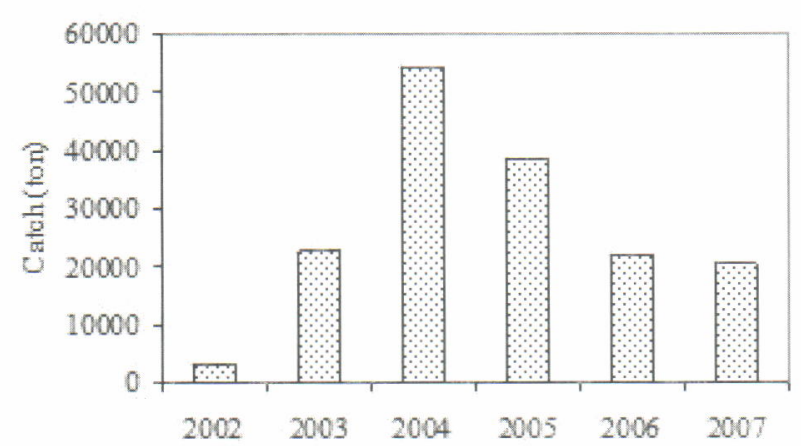

Figure 2.
Purse seine fisheries harvest in Pekalongan during period of 2002-2007 was fluctuated, both monthly, and annually. Monthly fluctuation of catch was presumably caused by the increase of fishing effort and changes in the pattern of fishing season. The rise and fall of fishing harvest were directly corresponding to variation number of fishing effort. Increase of fishing harvest during July until October (Figure 1), followed by the increasing number of purse seine fishing fleet (Figure 3 ), resulted in the decline of fishing harvest during October until March. The lower fishing harvest in October until March was likely affect the number of operating purse seine fishing fleet during the following months. According to Hariati et al. (2009), catch per unit of effort of small pelagic fish caught by purse seine in Pemangkat waters in 2005 has increased, while in 2006 this catch per unit of effort was decresaed.

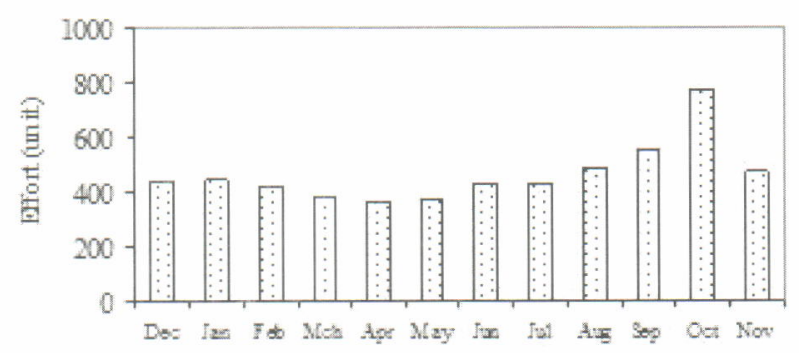

Figure 3.

Average monthly fluctuation of operating purse seine fishing fleet in Pekalongan Nusantara Fishing Port, 2002-2007.

The escalating price of fuel was responded by purse seine fishermen through reducing the number of operating fishing boat and by increasing the number of day during operational fishing cruise, resulted in the decreasing number of fishing efforts. According Hariati et al. (2009), the number of days at sea trawlers in Pemangkat during 2004-2006 showed a declining trend, that was likely due to the low number of active fishing vessels, especially at the end of 2005 and the increase in fuel prices. The reducing number of trawlers operating caused by price of fuel was also occured in Sibolga at the end of 2005 (Hariati \& Sadhotomo, 2007). Such fishing strategy was directed to save operational fishing costs, from and, to fishing grounds, because $45 \%$ of operational fishing costs was subject to fuel expenses. The changing pattern of fishing strategy also resulted in the variation of fish landing, both number and species.

The fluctuation of annual fish harvest was correlated with dynamics of marine resources available in the sea. As can be seen in Figure 4, the highest fishing 
yield was available in the year 2004 which was closely corresponds with increasing number of operating purse seine fishing fleet (1,749 units). Referring to the area of fishing ground, it was also observed in 2004 that most of purse seine fishing vessels based in Pekalongan Nusantara Fishing Port were concentrating their fishing effort in Makassar Strait and in the proximity of Masalima waters during second alternating season. On the hand, the decline of fishing harvest caused by the reducing number of operating purse seine fishing fleet, apart from the changes of fishing harvest species composition. The results correspond with Atmaja et al. (1986) confirming that Indian scad (Decapterus russelli) as the most common spesies in the catch in Java Sea. This study reveals that despite the alternating change of fish harvest composition in the Java Sea purse seine fisheries, Indian scad fish remains the most dominating harvested species.
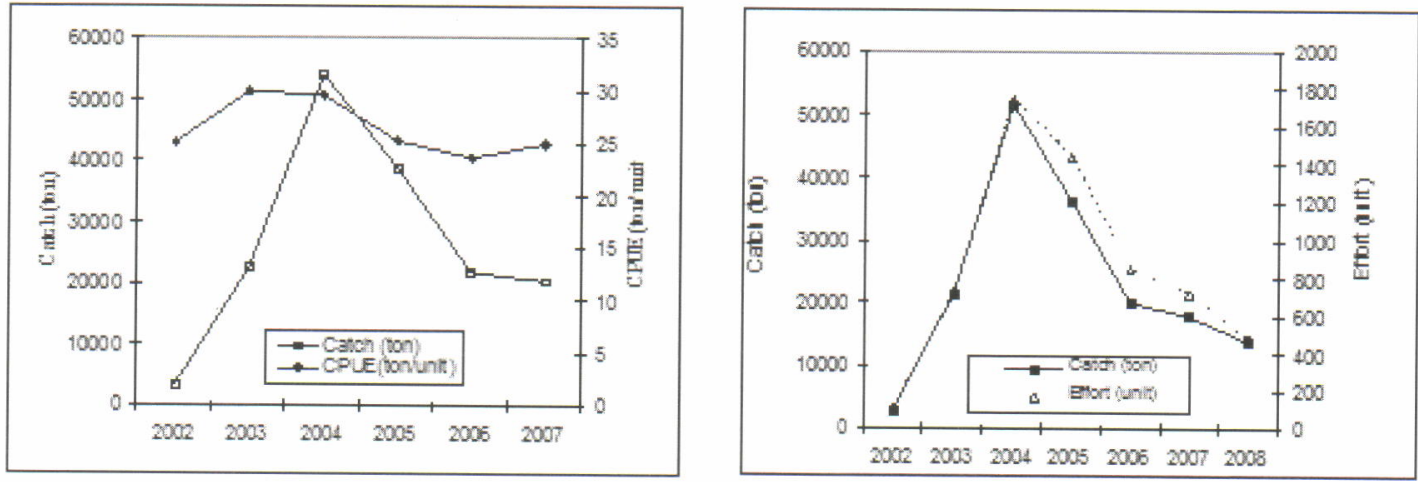

Figure 4. Dynamics of catch and effort from purse seine fisheries based in Pekalongan Nusantara Fishing Port, 2002-2007.

Fish abundance serves as the key of capture fisheries activities. If the number of harvested fish insufficient towards fishing effort that has been done, the corresponding result would be off days from fishing activities starting from the following day after the fishermen has landed until the next fishing season arrive. According to the results of this study, the highest annual fish abundance (catch per unit of effort) was observed in 2003 (Figure 5), while the highest annual fishing effort and harvest was occurred in 2004 (Figure 4). Referring to the monthly catch per unit of effort, the highest catch per unit of effort was recorded in August (36,34 tonnes/unit). The high number of catch per unit of effort would trigger fishers' motivation and resulted in peak fishing season in the Java Sea in August during 2002-2007 (Figure 5).

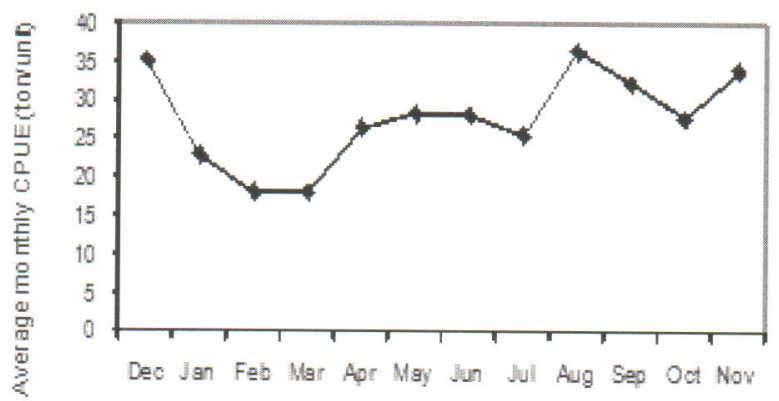

Figure 5. Average monthly catch per unit of effort, 2002-2007.
The changing pattern of harvesting fish will generate the expansion of fishing ground. The fishing ground expansion can be viewed through the spreading out area of fishing ground in searching for migrating fish and add up the number of operational fishing day in the sea. Atmaja et al. (1986) found there was a $167 \%$ increase in the number of operational fishing day in the sea from 4.2 days in 1976 to 11.2 days in 1984. In this study, it was found that average operational fishing day in the sea performed by most purse seine fishing fleet based in Pekalongan Nusantara Fishing Port was 73 days per trip.

\section{Fishing Grounds}

Operational fishing grounds for purse seine fishing fleets based in Pekalongan were located farther than other operational purse seine fleets in the north coasts of Java. At presents purse seine fleets based in Pekalongan, who previously operated in the surrounding waters of the Java Sea, were conducting their fishing operations all the way to Makassar Strait, South China Sea, and Natuna waters. According to the results of field observation, purse seine fleets based in Pekalongan usually perform their fishing activities in the waters adjacent to north part of Tegal and Pekalongan, Karimunjawa Islands, Bawean Island, Masalembo Islands, Matasiri Island, Kangean 
Island, Pejantan Island, Natuna, Midai, Tarempa, Tambelan (South China Sea), and waters of Lumu-
Lumu, Lari-Larian, also Kota Baru in the southern part of Makassar Strait, (Figure 6).

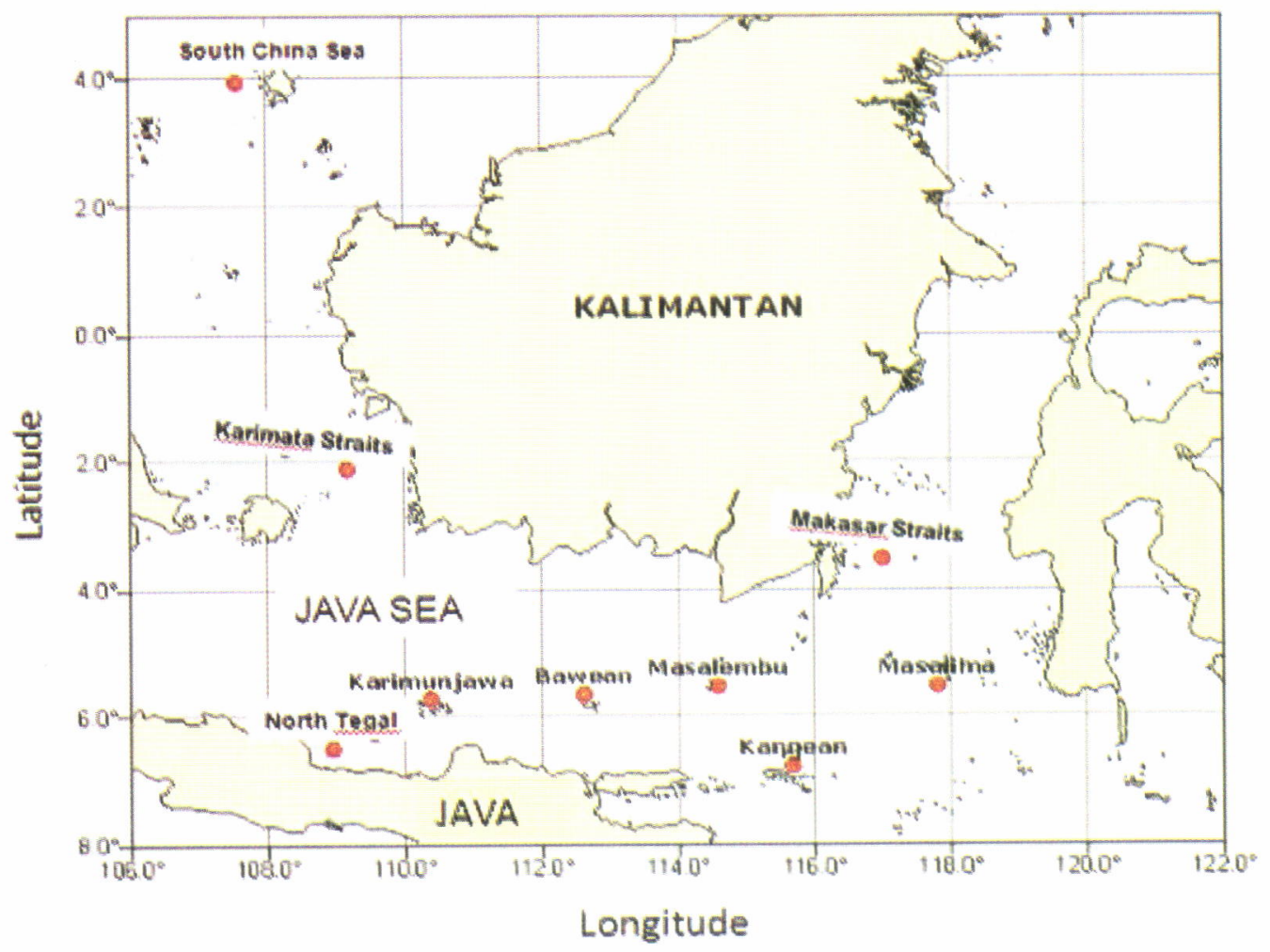

Figure 6. Indicative fishing ground of purse seine fleets based in Pekalongan, 2002-2007.

In general, purse seine fishers in Tegal, Pekalongan, and Juwana determin their fishing ground location based on the migration pattern of pelagic fish with reference to season and size structure. Fish skipper experience and knowledge will corresponds with changing nature condition (environmental change, migration pattern, and season) and potential fishing ground that enables greater benefit of capture fishieries; such condition applies for change in composition of fish harvest related with fishing ground (Atmaja \& Nugroho, 2003).

Fishing activities in the sea performed by purse seine fisheries based in Pekalongan Nusantara Fishing Port was carried out all year round. From the data 2002-2007 it was likely that higher fishing intensity occurred during west monsoon season (December to February). In 2002 and 2003, most purse seine fishing fleet focusing their fishing activities in Masalima waters, particularly during second intermonsoon season. In the following year, 2004, most fishing fleets were concentrated in Makassar Strait during west monsoon season and headed for Masalima waters during the second intermonsoon season. In 2005, the fishers change their fishing ground to Masalembo and
Makassar Strait during west monsoon season and first intermonsoon season; while during east monsoon season they moved to Bawean, Masalembo, and Masalima, as well as Makassar Strait and South China Sea. In second intermonsoon season they were focused in Masalima, Makassar Strait and Kangean waters. During west monsoon season in 2006, purse seine fishing ground was mostly concentrated in Makassar Strait, while during east monsoon season in Bawean waters, and moved to Kangean waters during second intermonsoon season. Similar profile also observed in the year 2007 , in which most waters in Makassar Strait serve as main fishing ground during west and in Kangean waters during second intermonsoon season.

The shift in fishing strategy were also observed in the longer time spent during fishing operation in the sea. From this study it was revealed that during west monsoon season, despite the heavy weather and high wave condition, and first intermonoon season up to $55 \%$ of fishermen continue their fishing activities and proceed their vessel to the Makassar Strait (Figure 7). Such tendency might be closely related with Sadhotomo (1998) finding, in which most big size 
pelagic fishes were associated with Matasiri and Makassar Strait waters during the end of east monsoon season (November until December) until the beginning of west monsoon season (January to March). On the contrary, during east monsoon season most fishermen focusing their fishing activities in the proximity of South China Sea (25\%). This corresponds with Sadhotomo \& Potier (1995) results which stated that during the first intermonsoon to east monsoon season (March until July) most big sized purse seine fishing vessels headed for South China Sea waters, while during second intermonsoon season they adjust their vessel's destination to the surrounding waters of the Masalima Islands. Other important facts revealed by this study were that purse seine fisheries based in Pekalongan Nusantara Fishing Port carried out their fishing operation almost all year round and that season has no longer serve as limiting factor for operational fishing day in the sea.

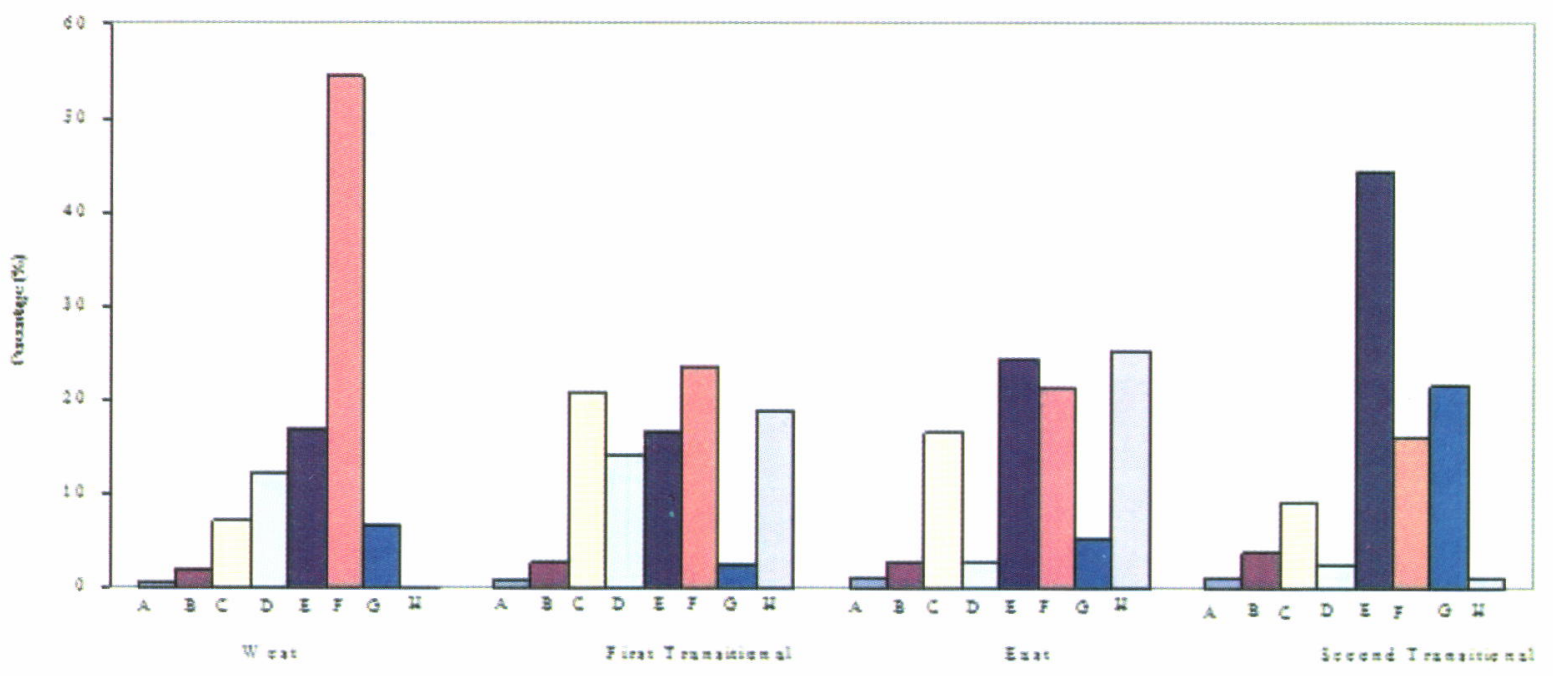

Figure 7. Distribution of purseiner based on season and fishing ground, 2002-2007.

Remarks: A: waters at north of Tegal and Pekalongan; B: waters in the proximity of Karimunjawa Islands; C: waters in the proximity of Bawean Island; D: waters in the proximity of Masalembo Islands; $E$ : waters in the proximity of Masalima Island; F: waters in the proximity of Makasar Strait; G: waters in the proximity of Kangean Islands; H: waters in the proximity of South China Sea

Referring to the results, it was implied that there was a dynamics of purse seine fishing grounds particularly purse seine fisheries based in Pekalongan Nusantara Fishing Port. The changing pattern of fishing ground was presumably affected by fishermen's behaviour in responding the shifting pattern of fisheries system and the dynamics of purse seine vessel movement. Another point of consideration would be season, in which it no longer serves as limiting factor in fishing operational system due to purse seine fisheries activities carry on all year around. Atmadja et al. (1986) mentioned the fact that fishing harvest would vary according to season and fishing ground. Moreover, Atmadja \& Sadhotomo (1985) stated the capability of purse seine fishing fleet operating in the Java Sea was more affected by vessel capacity in terms vessel size (gross tonnage).

\section{Fish Catch Composition}

Java Sea houses potential commodities of small pelagic fish. Six of sixteen fish species commonly harvest by fishermen were resulted from purse seine fisheries (Balai Riset Perikanan Laut, 2004). From Figure 8 , it is obvious that roundscads were the most dominant harvested fish $(52 \%)$ consisted of two species the Indian scad (Decapterus ruselli) and the shortfin scad (Decapterus macrosoma). The following species were commonly harvested, the spotted sardine (Amblygaster sirm), bigeye scad (Selar crumenophthalmus, Indian mackerel (Rastrelliger kanagurta), and sardines (Sardinella spp.). One large pelagic fish composing of only $5 \%$, was frigate mackerel (Auxis thazard) while other fish species compose $6.4 \%$ of the total harvest (Figure 8 ). 


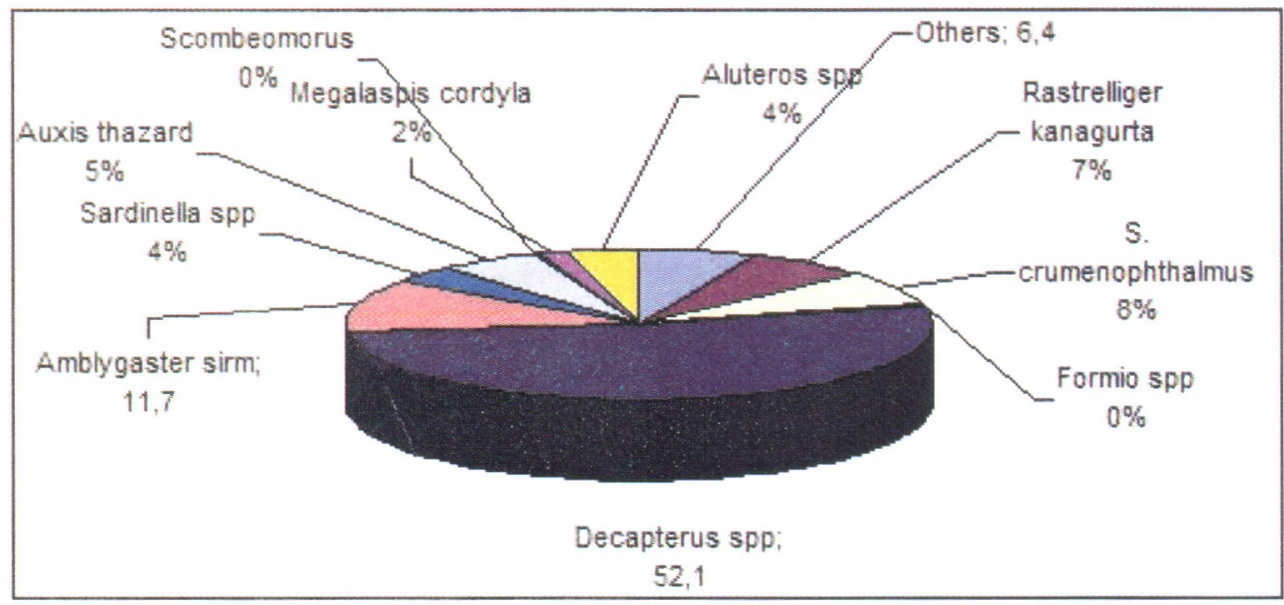

Figure 8. Catch composition of purse seine based in Pekalongan Nusantara Fishing Port, 2002-2007.

Catch composition of purse seine in relation to its fishing ground, showing different profile from one to another, although major harvest from each fishing ground was usually roundscads species. In Makassar Strait, other harvested fish species, apart from roundscad fish, were sardines and mackerels. The fish harvest fluctuation was probably resulted from changes of season. Changes in the environmental condition may affect several species in their migration pattern. Decapterus and Rastreliger for example, their migration route can be determined following the pattern of changes of waters salinity. Major change in salinity front pattern was infiuenced by seasonal changes of monsoon winds and seasonal migration profile. Chuliasorn \& Martosubroto (1986) stated that the waters off the west coast of Kuching, in the proximity of Natuna islands, was observed as spawning ground of indian scad and shortfin scad. Hariati et al. (2009) also emphasize the difference of dominating pelagic fish species at several areas in the South China Sea was resulted by the changing profile of geographic and local environmental factors, particularly sea surface salinity.

\section{CONCLUSIONS}

1. Fishing ground of purse seine fisheries based in Pekalongan Nusantara Fishing Port showed fluctuating profile, both in seasonal and annual basis.

2. During west monsoon season and first intermonsoon season, the concentration of purse seine fishing ground was in the waters of Lumu-Lumu, LariLarian, and Kota Baru (Makassar starit); while fishing ground during east monsoon season was spreaded in the waters of Pejantan, Natuna, Midai,
Tarempa, and Tambelan Island in the proximity of the South China Sea. Finally during second intermonsoon season most fishing fleets were operating in the waters of Masalima Islands.

\section{ACKNOWLEDGEMENTS}

This paper was part of the results of research on the developments mini puse seine after the collapse of big purse seine in the eastern part of the northern coast of Java, fiscal year 2007, at Research Institute for Marine Fisheries-Muara Baru, Jakarta.

\section{REFERENCES}

Atmadja, S. B. \& B. Sadhotomo. 1985. Aspek operasional pukat cincin di Laut Jawa. Jurnal Penelitian Perikanan Laut. Balai Penelitian Perikanan Laut. Jakarta. (32): 65-72.

Atmadja, S. B., Suwarso, \& S. Nurhakim. 1986. Hasil tangkapan pukat cincin menurut musim dan daerah penangkapan di Laut Jawa. Jurnal Penelitian Perikanan Laut. Balai Penelitian Perikanan Laut. Jakarta. (36): 57-65.

Atmadja, S. B. \& D. Nugroho. 2003. Pendugaan hasil tangkapan lestari ikan pelagis di Laut Jawa dan sekitarnya: Setelah penggunaan lampu sorot sebagai taktik penangkapan pukat cincin. Dalam Indrajaya, D. Setiapermana, \& Lukman, editor. Prosiding Hasil-Hasil Riset. Jakarta. Tanggal 4-5 Pebruari 2003. Pusat Riset Perikanan Tangkap. Badan Riset Kelautan dan Perikanan. Departemen Kelautan dan Perikanan. 31-38. 
Balai Riset Perikanan Laut. 2004. Musim Penangkapan Ikan di Indonesia. Departemen Kelautan dan Perikanan. Jakarta. 116 pp.

Chullasorn \& P. Martosubroto. 1986. Distribution and important biological features of coastal fish resources in Southeast Asia. Food and Agriculture Organization Fish. Tech. Paper. No.278. Food and Agriculture Organization. Rome. 160 pp.

Hariati, T. \& B. Sadhotomo. 2007. Aktivitas kapal pukat cincin Sibolga tahun 2002-2005 dan laju tangkap pukat rapat dan jarang pada periode Januari sampai Juli 2005 (pasca tsunami). Jurnal Penelitian Perikanan Indonesia. 13 (3): 179-190.

Hariati, T., U. Chodriyah, \& M. Taufik. 2009. Perikanan pukat cincin di Pemangkat, Kalimantan Barat. Jurnal Penelitian Perikanan Indonesia. 15 (1): 7991.
Sadhotomo, B. \& M. Potier. 1995. Exploratory scheme for the recruitment and migration of the main pelagic species. In M. Potier \& Nurhakim (Eds). Biology, Dinamic, and Exploitation of the small pelagic fishes in the Java SeaAARD/ORSTOM. 155-168.

Sadhotomo, B. 1998. Bioècologie des principales espèces pèlagiques exploitèes en mer de Java. Phd Thesis. Universitè de Monpellier II.

Sparre \& Venema. 1999. Introduction to tropical fish stock assessment. Part 1. Manual. Food and Agriculture Organization Fisheries Technical Paper No.306/1.Rev.2. 438 pp.

Wiyono, E. S. 2007. Dinamika harian hasil tangkapan rajungan (Portunus pelagicus) kaitannya dengan fase bulan di perairan Bondet, Cirebon. Buletin Pemanfaatan Sumber Daya Perikanan. XVI (1): 137-145. 